\title{
Transition metal nanoparticles stabilized by ammonium salts of hyperbranched polystyrene: effect of metals on catalysis of the biphasic hydrogenation of alkenes and arenes
}

\author{
Lei Gao $^{a}$, Keisuke Kojima ${ }^{b}$ and Hideo Nagashima ${ }^{\text {a,c }}{ }_{*}$ \\ ${ }^{a}$ Institute for Materials Chemistry and Engineering, Graduate School of Engineering Sciences, Kyushu University, Kasuga, Fukuoka 816-8580, Japan \\ ${ }^{b}$ Chemical Research Laboratories, Nissan Chemical Industry, Ltd., Funabashi, Chiba 274-8507, Japan \\ ${ }^{c}$ CREST, Japan Science and Technology Agency (JST), Kasuga, Fukuoka 816-8580, Japan
}

\section{ARTICLE INFO}

Article history:

Received

Received in revised form

Accepted

Available online

Keywords:
Nanoparticle
Hydrogenation
Hyperbranched polymer
Catalysis
Biphasic

\section{ABSTRACT}

Hyperbranched polystyrene bearing ammonium salts ( $\mathrm{HPS}-\mathrm{NR}_{3}{ }^{+} \mathrm{Cl}^{-}$) behaves as an excellent stabilizer of ruthenium, rhodium, iridium, palladium, and platinum nanoparticles from 1 to $3 \mathrm{~nm}$ in size uniformly dispersed in the polymer matrix. The catalytic performance of the resulting metal-polymer composites, M@HPS- $\mathrm{NR}_{3}{ }^{+} \mathrm{Cl}^{-}$, is dependent on the metal. This dependence was investigated by assessing the hydrogenation of alkenes and arenes. The utility of M@HPS$\mathrm{NR}_{3}{ }^{+} \mathrm{Cl}^{-}$as reusable catalysts in aqueous/organic biphasic systems was demonstrated by examining the catalysis of the hydrogenation of aromatic compounds containing various functional groups by $\mathrm{Ru} @ \mathrm{HPS}-\mathrm{NR}_{3}{ }^{+} \mathrm{Cl}^{-}$.

2009 Elsevier Ltd. All rights reserved.

* Corresponding author. Tel.: +81-92-583-7819; fax: +81-92-583-7819; e-mail: nagasima@ cm.kyushu-u.ac.jp 


\section{Introduction}

Due to increasing interest in environmentally benign chemical processes, high catalytic activity and catalyst recycling without leaching of metallic species into products are currently important issues. $^{1}$ The immobilization of metal compounds on solid supports, such that the catalyst may be separated from the product by filtration, is one potential solution that has been investigated on both laboratory and industrial scales. ${ }^{1,2}$ In addition, biphasic catalyst systems in which the catalyst is recovered from the product by simple phase separation is another possibility. ${ }^{1,3}$ The immobilization of organometallic species in solution has been widely investigated, and the immobilization of metal colloids in the aqueous phase ${ }^{4}$ has also received considerable attention, especially with regard to the use of transition metal nanoparticles (NPs). ${ }^{5}$

Small metal NPs are not inherently stable and will rapidly aggregate to form larger particles. However, they can be stabilized by the addition of appropriate compounds such as organic surfactants, heteroatom ligands, ionic liquids, and polymers. ${ }^{4,5}$ A typical example are tetraalkylammonium salts, which have been studied since the early days of NP chemistry. ${ }^{6}$ In a series of papers, Roucoux et al. reported the synthesis of NPs of late transition metals, including ruthenium, rhodium, iridium, palladium, and platinum, stabilized by tetraalkylammonium salts, and assessed the catalysis of these materials. ${ }^{7}$ Metal NPs dispersed in polyvinylpyrrolidone (PVP) has also been studied in detail. ${ }^{8}$ However, in such cases, the metal NPs stabilized by these conventional supports have been prepared in situ in water or alcohols and immediately used as catalysts, due to their continued instability. ${ }^{7,8}$ In fact, there are few examples of the isolation of these NPs in the solid state. ${ }^{9}$ Although applications of metal NP catalysts in the aqueous phase to biphasic catalysis have been examined, catalyst recycling has been reported infrequently, even in studies employing high substrate/catalyst (S/C) ratios. ${ }^{7}$ Since NPs supported by organoammonium salts or PVP cannot be dispersed in organic solvents, biphasic catalysis, in which the catalyst is in an organic phase and the substrate is in an aqueous phase, has rarely been investigated. In this context, the development of new supports for metal NPs has become a key issue with regard to the development of new catalytic systems, and improvements in supports, such as by the modification of PVP, have been actively pursued. ${ }^{10}$

The catalytic hydrogenation of alkenes, arenes, and ketones is often used to assess the catalytic properties of NPs supported by organic or polymeric stabilizers. ${ }^{4-10}$ Although metal NPs generally show good catalytic activity for alkene hydrogenation, it is more difficult to achieve arene hydrogenation with high activity and selectivity. ${ }^{11}$ As a result, arene hydrogenation is often performed at high temperatures under high $\mathrm{H}_{2}$ pressures. It is therefore desirable to identify highly reactive metal NP catalysts that will improve the reaction conditions. From the environmental point of

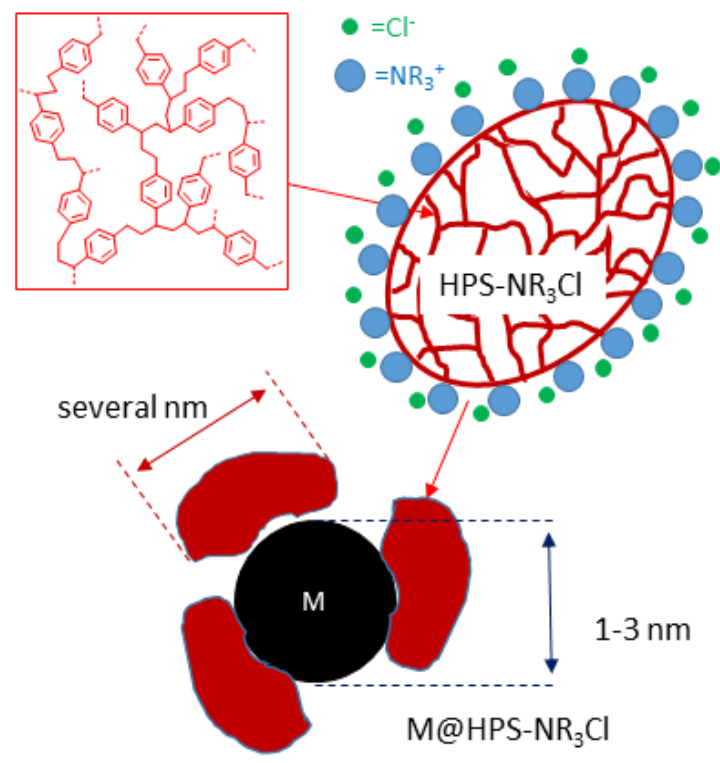

Figure 1. Molecular images of $\mathrm{HPS}-\mathrm{NR}_{3}{ }^{+} \mathrm{Cl}^{-}$and $\mathrm{M} @ \mathrm{HPS}-\mathrm{NR}_{3}{ }^{+} \mathrm{Cl}^{-}$.

view, the catalyst should be separated from the product with ease and it is also beneficial if the recovered catalyst is reusable. As well, with regard to organic synthesis, reactions should proceed with high selectivity under mild conditions. Of particular importance is the hydrogenation of aromatic compounds containing reducible functional groups. ${ }^{12}$

The selective hydrogenation of aromatic compounds containing glycidyl ether moieties while keeping the epoxido group intact is a typical goal, ${ }^{13 a}$ because epoxides are sensitive towards acids and bases and sometimes are reactive towards $\mathrm{H}_{2}$ in the presence of metal catalysts. ${ }^{13 a}$ However, dispersible metal NPs stabilized by conventional supports are often unstable in solution, resulting in aggregation of the metals. This is the reason why these catalysts typically exhibit high catalytic activity only at the initial stage of the reaction and are difficult to recycle without any decline in efficiency. ${ }^{14}$ To the best of our knowledge, there have been few reports of the hydrogenation of aromatic molecules including reducible functional groups, and no studies of the selective hydrogenation of substrates including epoxido groups.

Recently, we reported that the ammonium salts of hyperbranched polystyrene (HPS- $\mathrm{NR}_{3}{ }^{+} \mathrm{Cl}^{-}$) act as a novel stabilizer for metal NPs. ${ }^{15}$ Hyperbranched polymers are dendritic macromolecules having highly branched polymer chains and a spherical shape. ${ }^{16}$ It is noteworthy that many functional groups are present preferentially on the surfaces of such polymers. The ammonium salts of hyperbranched polystyrene ( $\mathrm{HPS}-\mathrm{NR}_{3}{ }^{+} \mathrm{Cl}^{-}$) are readily prepared in three steps starting from a monomer, and are now produced on industrial scales. ${ }^{15 a}$ The excellent properties of HPS- $\mathrm{NR}_{3}{ }^{+} \mathrm{Cl}^{-}$as metal NP supports have been studied by our own research group, and $\mathrm{M} @ \mathrm{HPS}-\mathrm{NR}_{3}{ }^{+} \mathrm{Cl}^{-}$containing gold, palladium, and platinum NPs 1 to $3 \mathrm{~nm}$ in size have been successfully prepared (Figure 1). The resulting M@HPS- $\mathrm{NR}_{3}{ }^{+} \mathrm{Cl}^{-}$ $(\mathrm{M}=\mathrm{Au}, \mathrm{Pt}$, or $\mathrm{Pd})$ are dispersible in a variety of solvents by judicious choice of the $\mathrm{R}$ group, and exhibit good catalytic activity for the biphasic hydrogenation of alkenes ${ }^{15 a}$ and the aerobic oxidation of alcohols with $\mathrm{O}_{2}{ }^{15 \mathrm{~b}}$ The recycling of these catalysts through simple phase separation is also readily achieved. These results prompted us to assess M@HPS- $\mathrm{NR}_{3}{ }^{+} \mathrm{Cl}^{-}$ with regard to arene hydrogenation. In this paper, we describe the preparation and catalysis of ruthenium, rhodium, and iridium NPs supported by $\mathrm{HPS}-\mathrm{NR}_{3}{ }^{+} \mathrm{Cl}^{-}$. The catalytic properties of these 
newly prepared M@HPS- $\mathrm{NR}_{3}{ }^{+} \mathrm{Cl}^{-}$are first compared with those of the previously reported $\mathrm{Pd}$ and $\mathrm{Pt} @ \mathrm{HPS}-\mathrm{NR}_{3}{ }^{+} \mathrm{Cl}^{-}$catalysts based on the hydrogenation of several alkenes and toluene. Although Ru@ $\mathrm{HPS}-\mathrm{NR}_{3}{ }^{+} \mathrm{Cl}^{-}$was not an efficient catalyst for the hydrogenation of alkenes compared with the rhodium, palladium, and platinum homologues, it was applicable to the hydrogenation of aromatic compounds bearing reducible functional groups. Two types of water/organic biphasic hydrogenation, in which the catalyst was in either the organic or the aqueous phase, were achieved, and the catalyst phase was reusable without any decline of catalyst efficiency. Furthermore, no metal leaching was observed.

\section{Results and Discussion}

\subsection{Preparation of ruthenium, rhodium, and iridium NPs stabilized by $\mathrm{HPS}-\mathrm{NR}_{3}{ }^{+} \mathrm{Cl}$}

As reported previously, Pd and Pt NPs supported by the ammonium salts of hyperbranched polystyrene (HPS- $\mathrm{NR}_{3}{ }^{+} \mathrm{Cl}, \mathrm{R}$ $=n$-butyl $(n \mathrm{Bu})$ or $n$-octyl $(n \mathrm{Oct}))$ were prepared by the thermal decomposition of $\mathrm{Pd}_{2}(\mathrm{dba})_{3} \cdot \mathrm{CHCl}_{3}$ or $\mathrm{Pt}(\mathrm{dba})_{2}$ in the presence of HPS- $\mathrm{NR}_{3}{ }^{+} \mathrm{Cl}^{-}$. As such, four of these material were prepared according to methods reported previously: Pt@HPS-N $n \mathrm{Bu}_{3}{ }^{+} \mathrm{Cl}^{-}$ (Pt-1), Pd@ HPS-N $n \mathrm{Bu}_{3}{ }^{+} \mathrm{Cl}^{-}$(Pd-1), Pt@HPS-N $n \mathrm{Oct}_{3}{ }^{+} \mathrm{Cl}^{-}$(Pt-2), and $\mathrm{Pd} @ \mathrm{HPS}-\mathrm{N} n \mathrm{Oct}_{3}{ }^{+} \mathrm{Cl}^{-}$(Pd-2). ${ }^{15 \mathrm{a}, 15 \mathrm{c}}$ The ruthenium (Ru), rhodium (Rh), and iridium (Ir) NPs stabilized by the HPS$\mathrm{NR}_{3}{ }^{+} \mathrm{Cl}^{-}$were synthesized by the $\mathrm{NaBH}_{4}$ reduction of $\mathrm{MCl}_{3} \cdot 3 \mathrm{H}_{2} \mathrm{O}$ $\left(\mathrm{M}=\mathrm{Ru}, \mathrm{Rh}\right.$, or Ir) in the presence of HPS- $\mathrm{NR}_{3}{ }^{+} \mathrm{Cl}^{-}$(Scheme 1). The preparation of Ru-1, Rh-1, and Ir-1 NPs stabilized by HPS$\mathrm{N} n \mathrm{Bu}_{3}{ }^{+} \mathrm{Cl}^{-}$was carried out in water, whereas aqueous THF was used for the synthesis of Ru-2, Rh-2, and Ir-2 NPs supported by HPS-N $n \mathrm{Oct}_{3}{ }^{+} \mathrm{Cl}^{-}$. Since HPS- $\mathrm{NR}_{3}{ }^{+} \mathrm{Cl}^{-}$contains both hydrophobic portions, due to the polystyrene backbone, and hydrophilic regions, due to the charge on the ammonium groups, the dispersibility of M@HPS- $\mathrm{NR}_{3}{ }^{+} \mathrm{Cl}^{-}$was tunable by employing the appropriate $\mathrm{R}$ group. As an example, M@HPS-N $n \mathrm{Bu}_{3}{ }^{+} \mathrm{Cl}^{-}$was readily dispersed in water but not in toluene or EtOAc. In contrast, M@HPS-NnOct ${ }_{3}^{+} \mathrm{Cl}^{-}$could be dispersed in common organic solvents but not in water. Alcohols were good solvents for both of these materials.

Scheme 1 shows the preparative procedures and transmission electron microscopy (TEM) images of representative samples of Ru-1, Rh-1, Ir-1, Pd-1, and Pt-1. The average NP sizes and size distributions in these materials are summarized in Table 1. In all cases, the NPs were uniform and had average particle sizes in the range of 1 to $3 \mathrm{~nm}$. The metal content of each M@HPS- $\mathrm{NR}_{3}{ }^{+} \mathrm{Cl}^{-}$ was 9 to $13 \mathrm{wt} \%$, as determined by inductively coupled plasmamass spectrometry (ICP-MS) analysis (Table 1). It is known that metal NPs stabilized by organic ammonium salts or PVP are only stable in the solution state, such that removal of the solvent causes precipitation of the bulk metals. ${ }^{7-9}$ In sharp contrast, M@HPS- $\mathrm{NR}_{3}{ }^{+} \mathrm{Cl}^{-}$could be stored for over a month either in solution or in the solid state under aerobic conditions. No precipitate was

Table 1. Metal content and nanoparticle size of M@HPS$\mathrm{NR}_{3}{ }^{+} \mathrm{Cl}$

\begin{tabular}{cccc}
\hline entry & \multirow{2}{*}{ Metal NPs } & $\begin{array}{c}\text { Metal content } \\
\%)\end{array}$ & Particle size $^{\mathrm{a}}(\mathrm{wm})$ \\
\hline 1 & Ru-1 & 12 & $1.7 \pm 0.3$ \\
2 & Ru-2 & 12 & $1.2 \pm 0.2$ \\
3 & Rh-1 & 12 & $1.9 \pm 0.4$ \\
4 & Rh-2 & 13 & $1.7 \pm 0.3$ \\
5 & Ir-1 & 9 & $1.9 \pm 0.4$ \\
6 & Ir-2 & 9 & $1.7 \pm 0.3$ \\
7 & Pd-1 & 9 & $2.1 \pm 0.4$ \\
8 & Pd-2 & 11 & $2.3 \pm 0.4$ \\
9 & Pt-1 & 11 & $1.9 \pm 0.3$ \\
10 & Pt-2 & 11 & $1.7 \pm 0.4$ \\
\hline a Determined by ICP-MS; ${ }^{b}$ Measured by TEM
\end{tabular}

${ }^{\mathrm{a}}$ Determined by ICP-MS; ${ }^{\mathrm{b}}$ Measured by TEM.

(1) $M=R u, R h, I r$

$$
\begin{aligned}
& \mathrm{MCl}_{3} 3 \mathrm{H}_{2} \mathrm{O}+\mathrm{HPS}-\mathrm{N} n \mathrm{Bu}_{3}{ }^{+} \mathrm{Cl}^{-} \frac{\mathrm{NaBH}_{4}}{\mathrm{H}_{2} \mathrm{O}} \rightarrow \mathrm{M@HPS-N} n \mathrm{Bu}_{3}{ }^{+} \mathrm{Cl}^{-} \\
& M=R u(R u-1), \operatorname{Rh}(\mathbf{R h}-1), \operatorname{Ir}(\operatorname{lr}-1)
\end{aligned}
$$

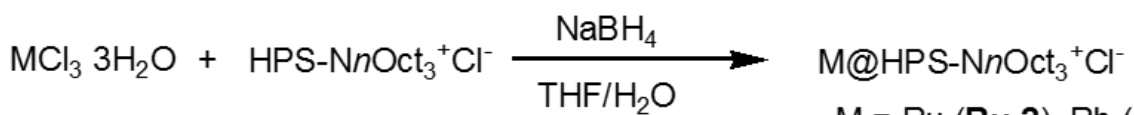

$$
\begin{aligned}
& M=R u \text { (Ru-2), Rh (Rh-2), Ir (Ir-2) }
\end{aligned}
$$

(2) $M=P d, P t$
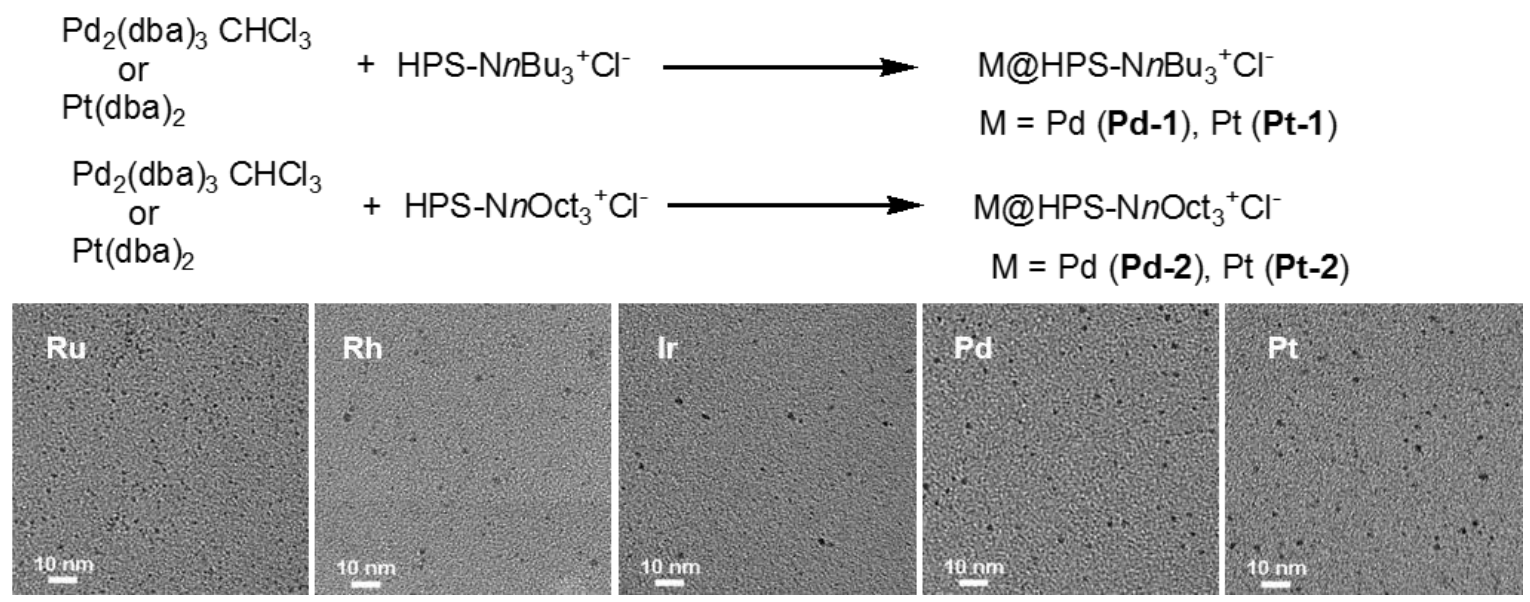

Scheme 1. Preparation of Ru, Rh, Ir, Pd, and Pt nanoparticles stabilized by HPS- $\mathrm{NR}_{3}{ }^{+} \mathrm{Cl}^{-}$and TEM images of Ru-1, Rh-1, Ir-1, Pd-1, and Pt-1. Images of Ru-2, Rh-2, Ir-2, Pd-2, and Pt-2 are presented in the Supporting Information.

observed from the stock solution over this time span. As well, there were no evident differences in the dispersibility of the solid sample before and after storage, and neither the particle size of the $\mathrm{M} @ \mathrm{HPS}-\mathrm{NR}_{3}{ }^{+} \mathrm{Cl}^{-}$nor the catalytic activity was changed. The 
former was evidenced by TEM images of Ru-1 after storage forone month in an aqueous solution or in the solid state, as shown in the Supporting Information, whereas the latter was proved by toluene hydrogenation under standard conditions ( $\mathrm{S} / \mathrm{C}$ $=333, \mathrm{P}_{\mathrm{H} 2}=30 \mathrm{~atm}, 30{ }^{\circ} \mathrm{C}, 1 \mathrm{~h}$ ). The $>99 \%$ yield obtained from this trial was comparable to that shown in Table 5, entry 17.



The catalytic properties of the M@HPS- $\mathrm{NR}_{3}{ }^{+} \mathrm{Cl}^{-}$materials were investigated by studying the hydrogenation of mono-, di-, tri-, and tetrasubstituted alkenes at $30{ }^{\circ} \mathrm{C}$ under 1 atm of $\mathrm{H}_{2}{ }^{17}$ The reactions were carried out in $\mathrm{EtOH}$, which gave a homogeneous solution of the catalyst and the substrate. The substrate/catalyst ratio (S/C) was set at 500. The hydrogenations of 1-octene and cyclohexene were examined, and the results of cyclohexene hydrogenation are summarized in Table 2 . The high catalytic activities of the rhodium (Rh-1, Rh-2), palladium (Pd-1, Pd-2), and platinum catalysts (Pt-1, Pt-2) were clearly demonstrated, and each reaction was complete within $1 \mathrm{~h}$ (entries 4-5, 8-11). The ruthenium catalyst did not exhibit catalytic activity under 1 atm of $\mathrm{H}_{2}$, although the reaction did proceed under 10 atm of $\mathrm{H}_{2}$ (entries 1-3). In contrast, the catalytic activity of the iridium compounds was significantly lower. It should be noted that there was no substantial difference in catalytic activity between the two supports, HPS- $\mathrm{NBu}_{3} \mathrm{Cl}^{-}$and $\mathrm{HPS}-\mathrm{N}_{n} \mathrm{Oct}_{3}{ }^{+} \mathrm{Cl}^{-}$, as long as $\mathrm{EtOH}$ was used as the solvent. Similar results were obtained for the hydrogenation of 1-octene and 1methylcyclohexene, as described in the Supporting Information.

It is well known that the efficient hydrogenation of tetrasubstituted alkenes is challenging when using conventional catalysts. $^{2,17,18}$ Table 3 shows the results of the hydrogenation of 2,3-dimethyl-2-butene, in which a higher $\mathrm{H}_{2}$ pressure (10 atm) is

Table 2. Hydrogenation of cyclohexene over M@HPS$\mathrm{NR}_{3}{ }^{+} \mathrm{Cl}^{-}$in $\mathrm{EtOH}$ at $30{ }^{\circ} \mathrm{C}(\mathrm{S} / \mathrm{C}=500) .{ }^{\text {a }}$

\begin{tabular}{|c|c|c|c|c|c|}
\hline entry & Reaction & Cat & $\mathrm{P}\left(\mathrm{H}_{2}\right)$ & Time (h) & Conv. $^{\mathrm{b}}(\%)$ \\
\hline 1 & & Ru-1 & 10 & 3 & $>99$ \\
\hline 2 & & Pu & 10 & 1 & 15 \\
\hline 3 & & Ku-2 & 10 & 3 & $>99$ \\
\hline 4 & & Rh-1 & 1 & 1 & $>99$ \\
\hline 5 & & Rh-2 & 1 & 1 & $>99$ \\
\hline 6 & & Ir-1 & 10 & 3 & 21 \\
\hline 7 & & Ir-2 & 10 & 3 & 13 \\
\hline 8 & & Pd-1 & 1 & 1 & $>99$ \\
\hline 9 & & Pd-2 & 1 & 1 & $>99$ \\
\hline 10 & & Pt-1 & 1 & 1 & $>99$ \\
\hline 11 & & Pt-2 & 1 & 1 & $>99$ \\
\hline
\end{tabular}

${ }^{\mathrm{a}}$ The reaction was carried out with the catalyst $(0.2 \mathrm{~mol} \%)$ in EtOH $(2 \mathrm{~mL})$ for $1 \mathrm{~h}$ at $30{ }^{\circ} \mathrm{C}$ under hydrogen pressure as indicated in the table. ${ }^{b}$ Determined by GC with $n$-decane as an internal standard.

Table 3. Hydrogenation of 2,3-dimethyl-2-butene over $\mathrm{M} @ \mathrm{HPS}-\mathrm{NR}_{3}{ }^{+} \mathrm{Cl}^{-}$in $\mathrm{EtOH}$ at $30{ }^{\circ} \mathrm{C}(\mathrm{S} / \mathrm{C}=500){ }^{\mathrm{a}}$

\begin{tabular}{|c|c|c|c|c|c|}
\hline entry & Reaction & Cat & $\mathrm{P}\left(\mathrm{H}_{2}\right)$ & Time (h) & Conv. $^{\mathrm{b}}(\%)$ \\
\hline 1 & & Ru-1 & 10 & 1 & 73 \\
\hline 2 & & Ru-2 & 10 & 3 & $>99$ \\
\hline 3 & & Rh-1 & 10 & 1 & 97 \\
\hline 4 & & Rh-2 & 10 & 3 & $>99$ \\
\hline 5 & & Ir-1 & 10 & 3 & 0 \\
\hline 6 & & Ir-2 & 10 & 3 & 0 \\
\hline 7 & & Pd-1 & 10 & 3 & 66 \\
\hline 8 & & Pd-2 & 10 & 3 & 82 \\
\hline 9 & & Pt-1 & 10 & 3 & $>99$ \\
\hline 10 & & Dt? & 1 & 3 & $>99$ \\
\hline 11 & & Pt-2 & 10 & 3 & $>99$ \\
\hline
\end{tabular}

${ }^{\mathrm{a}}$ The reaction was carried out with the catalyst $(0.2 \mathrm{~mol} \%)$ in EtOH $(2 \mathrm{~mL})$ at $30{ }^{\circ} \mathrm{C}$ under hydrogen pressure as indicated in the table.. ${ }^{\mathrm{b}}$ Determined by ${ }^{1} \mathrm{H}$ NMR using mesitylene as an internal standard.

Table 4. Selected examples of the mono- and biphasic hydrogenation of cyclohexene to ascertain the highest TOF $\left(\mathrm{h}^{-}\right.$ $\left.{ }^{1}\right)$ values for Rh-1, Pd-1, and Pt-1. ${ }^{\text {a }}$

\begin{tabular}{cccccc}
\hline entry & Cat & Solvent & S/C & $\begin{array}{c}\text { Conv }^{\text {b }} \\
(\%)\end{array}$ & TOF $\left(h^{-1}\right)$ \\
\hline 1 & Rh-1 & EtOH & 5000 & $>99$ & 5000 \\
2 & Rh-1 & EtOH & 10000 & 87 & 8700 \\
3 & Pd-1 & EtOH & 5000 & $>99$ & 5000 \\
4 & Pd-1 & EtOH & 10000 & 83 & 8300 \\
5 & Pt-1 & EtOH & 5000 & $>99$ & 5000 \\
6 & Pt-1 & EtOH & 10000 & 52 & 5200 \\
7 & Rh-1 & EtOAc/ $\mathrm{H}_{2} \mathrm{O}$ & 5000 & 76 & 3800 \\
8 & $\mathbf{P d - 1}$ & EtOAc/ $\mathrm{H}_{2} \mathrm{O}$ & 5000 & 75 & 3750 \\
9 & $\mathbf{P t - 1}$ & EtOAc/ $\mathrm{H}_{2} \mathrm{O}$ & 5000 & 32 & 1600 \\
\hline
\end{tabular}

${ }^{a}$ The reaction was carried out with the catalyst $(0.01 \sim 0.02$ $\mathrm{mol} \%)$ in EtOH $(2 \mathrm{~mL})$ or a mixture of EtOAc $(2 \mathrm{~mL})$ and $\mathrm{H}_{2} \mathrm{O}$ $(2 \mathrm{~mL})$ for $1 \mathrm{~h}$ at $30{ }^{\circ} \mathrm{C}$ under a hydrogen atmosphere (1 atm). ${ }^{\mathrm{b}}$ Determined by GC with $n$-decane as an internal standard.

seen to be necessary to complete the hydrogenation reaction within the span of a few hours. It is of interest that the activity of the ruthenium catalysts was comparable to that of the rhodium and platinum catalysts under 10 atm of $\mathrm{H}_{2} \cdot{ }^{19}$ The palladium catalysts showed somewhat lower activity under the same conditions and, again, the iridium catalysts were not effective even under 10 atm of $\mathrm{H}_{2}$.

Trials using lower catalyst loadings showed that the initial catalytic activity was dependent on the metal employed, as evident from Table 4. Using Rh-1, Pd-1, or Pt-1 as the catalyst, the hydrogenation of cyclohexene could be performed at $30{ }^{\circ} \mathrm{C}$ under $1 \mathrm{~atm}$ of $\mathrm{H}_{2}$ in $1 \mathrm{~h}$. All of the reactions went to completion at an S/C ratio of 5000. In trials for which S/C was set at 10,000, the conversions varied from 50 to $90 \%$, from which the turnover frequency (TOF) values for Rh-1, Pd-1, and Pt-1 can be estimated to be 5000 to $9000 \mathrm{~h}^{-1}$ under these conditions. The TOF values of these nanoparticle catalysts were comparable or higher than those reported in the literature. ${ }^{20}$ As an example, Hensen and coworkers have recently reported the hydrogenation of 1-octene with Rh NPs stabilized by PVP, in which the TOF at $70{ }^{\circ} \mathrm{C}$ was $10,000 \mathrm{~h}^{-1}$. $20 \mathrm{a}$

The advantage of the M@HPS- $\mathrm{NBu}_{3}{ }^{+} \mathrm{Cl}^{-}$series is its unique dispersibility in solvents, such that it is dispersible in water but not soluble in EtOAc. Biphasic hydrogenation, in which the cyclohexene was in the organic phase and the catalyst was in the aqueous phase, was therefore examined using Rh-1, Pd-1, or Pt1 as the catalyst (Table 4, entries 7-9). Although the catalytic activity was somewhat lower than that observed during the single phase experiment in $\mathrm{EtOH}$, the reaction proceeded smoothly and TOF values reached 1600,3750 , and $3800 \mathrm{~h}^{-1}$ in the trials using Pt-1, Pd-1, and Rh-1, respectively. This suggests the possibility of recycling the catalyst by phase separation, and results of such tests are described further on.

\subsection{Catalytic hydrogenation of toluene by $\mathrm{M} @ \mathrm{HPS}-\mathrm{NR}_{3}{ }^{+} \mathrm{Cl}$}

Similar experiments for the hydrogenation of toluene generated different results from those obtained during the hydrogenation of alkenes. The reactions shown in Table 5 were performed at $30{ }^{\circ} \mathrm{C}$ for $1 \mathrm{~h}$. When $\mathrm{EtOH}$ was used as the solvent, the iridium, palladium and platinum catalysts did not show any reactivity even under 30 atm of $\mathrm{H}_{2}$. In sharp contrast, the rhodium catalysts showed some activity and the ruthenium catalysts, under 30 atm of $\mathrm{H}_{2}$, gave the highest activity among the various trials. In experiments with $\mathrm{S} / \mathrm{C}=2000$, a TON value of 1540 was achieved (representing a $77 \%$ toluene conversion) after $5 \mathrm{~h}$ when 
Ru-1 was used as the catalyst, whereas the reaction went to completion (TON > 2000) when employing Ru-2. The trials investigating biphasic catalysis $\left(\mathrm{S} / \mathrm{C}=333\right.$ at $30{ }^{\circ} \mathrm{C}$ for $1 \mathrm{~h}$ ) were carried out using M@HPS- $\mathrm{NR}_{3}{ }^{+} \mathrm{Cl}^{-}$with the catalyst immobilized in the

Table 5. Mono- and biphasic hydrogenation of toluene with $\mathrm{M} @ \mathrm{HPS}-\mathrm{NR}_{3}{ }^{+} \mathrm{Cl}^{-}$

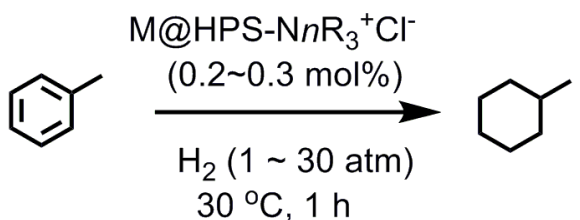

\begin{tabular}{|c|c|c|c|c|c|}
\hline entry & catalyst & solvent & $\begin{array}{l}\mathrm{H}_{2} \\
\text { (atm) }\end{array}$ & $\begin{array}{l}\text { conv. } \\
\text { d }(\%)\end{array}$ & $\begin{array}{l}\text { TOF } \\
\left(\mathrm{h}^{-1}\right)\end{array}$ \\
\hline 1 & \multirow{2}{*}{ Rh-1 } & $\mathrm{EtOH}^{\mathrm{a}}$ & 30 & 10 & 50 \\
\hline 2 & & $\mathrm{H}_{2} \mathrm{O}^{\mathrm{b}}$ & 30 & 50 & 167 \\
\hline 3 & Rh-2 & $\mathrm{EtOH}^{\mathrm{a}}$ & 30 & trace & - \\
\hline 4 & \multirow{2}{*}{ Ir-1 } & $\mathrm{EtOH}^{\mathrm{a}}$ & 30 & trace & -- \\
\hline 5 & & $\mathrm{H}_{2} \mathrm{O}^{\mathrm{b}}$ & 30 & $<1$ & -- \\
\hline 6 & Ir-2 & $\mathrm{EtOH}^{\mathrm{a}}$ & 30 & 0 & -- \\
\hline 7 & \multirow{2}{*}{ Pd-1 } & $\mathrm{EtOH}^{\mathrm{a}}$ & 30 & 0 & -- \\
\hline 8 & & $\mathrm{H}_{2} \mathrm{O}^{\mathrm{b}}$ & 30 & 0 & -- \\
\hline 9 & Pd-2 & $\mathrm{EtOH}^{\mathrm{a}}$ & 30 & 0 & - \\
\hline 10 & \multirow{2}{*}{ Pt-1 } & $\mathrm{EtOH}^{\mathrm{a}}$ & 30 & trace & -- \\
\hline 11 & & $\mathrm{H}_{2} \mathrm{O}^{\mathrm{b}}$ & 30 & trace & -- \\
\hline 12 & Pt-2 & $\mathrm{EtOH}^{\mathrm{a}}$ & 30 & trace & -- \\
\hline 13 & \multirow{10}{*}{ Ru-1 } & $\mathrm{EtOH}^{\mathrm{a}}$ & 30 & 35 & 175 \\
\hline 14 & & $\mathrm{H}_{2} \mathrm{O}^{\mathrm{b}}$ & 1 & 8 & 27 \\
\hline 15 & & $\mathrm{H}_{2} \mathrm{O}^{\mathrm{b}}$ & 5 & 30 & 100 \\
\hline 16 & & $\mathrm{H}_{2} \mathrm{O}^{\mathrm{b}}$ & 10 & 95 & 316 \\
\hline 17 & & $\mathrm{H}_{2} \mathrm{O}^{\mathrm{b}}$ & 30 & $>99$ & $>333$ \\
\hline $18^{\mathrm{e}}$ & & $\mathrm{H}_{2} \mathrm{O}^{\mathrm{b}}$ & 30 & 27 & 900 \\
\hline 19 & & $\mathrm{EtOAc} / \mathrm{H}_{2} \mathrm{O}^{\mathrm{c}}$ & 30 & $>99$ & $>333$ \\
\hline 20 & & $n$-Hexane/ $\mathrm{H}_{2} \mathrm{O}^{\mathrm{c}}$ & 30 & 48 & 160 \\
\hline 21 & & $\mathrm{CH}_{2} \mathrm{Cl}_{2} / \mathrm{H}_{2} \mathrm{O}^{\mathrm{c}}$ & 30 & 6 & 20 \\
\hline 22 & & $\mathrm{Et}_{2} \mathrm{O} / \mathrm{H}_{2} \mathrm{O}^{\mathrm{c}}$ & 30 & 92 & 306 \\
\hline 23 & Ru-2 & $\mathrm{EtOH}^{\mathrm{a}}$ & 30 & 52 & 260 \\
\hline
\end{tabular}

${ }^{a}$ The reaction was carried out in $\mathrm{EtOH}$ in the presence of the catalyst $(0.2 \sim 0.3 \mathrm{~mol} \%)$ at $30{ }^{\circ} \mathrm{C}$ for $1 \mathrm{~h}$. ${ }^{\mathrm{b}}$ The reaction was performed in water with $0.3 \mathrm{~mol} \%$ catalyst. ${ }^{\mathrm{c}} \mathrm{A} 1 / 1$ mixture of water and organic solvent was used for the biphasic system with $0.3 \mathrm{~mol} \%$ catalyst. ${ }^{\mathrm{d}}$ Determined by GC analysis with $n$-decane as an internal standard. ${ }^{\mathrm{e}} 0.03$ mol\% Ru-1 was used $(\mathrm{S} / \mathrm{C}=3333)$.

aqueous phase. In the absence of an organic solvent, no reaction took place when using Ir-1, Pd-1, or Pt-1, although Ru-1 exhibited good catalytic performance under from 1 to $30 \mathrm{~atm}$ of $\mathrm{H}_{2}$. The reaction thus took place even under 1 atm of $\mathrm{H}_{2}$, although the conversion of toluene was less than $10 \%$ (TOF $=27$ $\mathrm{h}^{-1}$ ). The effect of hydrogen pressure was significant in the hydrogenation reactions catalyzed by Ru-1, and the TOF value could be increased by raising the hydrogen pressure, such that the reaction was complete within $1 \mathrm{~h}$ under $30 \mathrm{~atm}$ of $\mathrm{H}_{2}$. When the $\mathrm{S} / \mathrm{C}$ was set at 3333 , the conversion after $1 \mathrm{~h}$ was $27 \%$, corresponding to a TOF of $900 \mathrm{~h}^{-1}$, a value that is higher than previous values reported in the literature. ${ }^{21}$ The addition of organic solvents to this aqueous catalyst system led to biphasic hydrogenation, and good TOF values were obtained when either EtOAc or $\mathrm{Et}_{2} \mathrm{O}$ was used as the organic phase.

It was curious that the rhodium catalysts did not show good catalytic performance for the hydrogenation of toluene, since rhodium NPs have been shown to efficiently catalyze the hydrogenation of arenes. ${ }^{22,23}$ The lower conversion observed in the case of toluene was ascribed to the facile decomposition of the catalyst under the reaction conditions. When Rh-1 was used as the catalyst, TEM images after the hydrogenation showed the presence of large particles in either EtOH or $\mathrm{H}_{2} \mathrm{O}$. In contrast, no catalyst deactivation or aggregation of Rh NPs was observed following alkene hydrogenation with Rh-1 under 1 atm of $\mathrm{H}_{2}$. These catalysts were also found to be recyclable, as described further on. Consequently, it is likely that the application of high $\mathrm{H}_{2}$ pressures induced the rapid aggregation of the Rh NPs.

\subsection{Catalytic hydrogenation of arenes with functional groups}

The utility of Ru-1 was demonstrated by the hydrogenation of substituted arenes in water, as shown in Table $6[\mathrm{~S} / \mathrm{C}=333$ under $\mathrm{H}_{2} \quad(30$ atm)]. Toluene, phenol, and anisole underwent hydrogenation smoothly at $30{ }^{\circ} \mathrm{C}$ under 30 atm of $\mathrm{H}_{2}$. After $1 \mathrm{~h}$, the corresponding products methylcyclohexane, cyclohexanol, and methyl cyclohexyl ether, respectively, were obtained in quantitative yields (entries 1-3). Hydrogenation of phenol resulted in the exclusive formation of cyclohexanol, although the generation of cyclohexanone has been reported in certain cases. ${ }^{13 a}$ Compared with these substrates, the hydrogenation of acetophenone under the same conditions was slower, since the reduction of the ketone was competing with arene hydrogenation (entry 4). The hydrogenations of benzonitrile, nitrobenzene, and bromobenzene did not take place under these conditions. At 80 ${ }^{\circ} \mathrm{C}$, aniline was formed $(79 \%$ over $5 \mathrm{~h}$ ) from nitrobenzene, whereas in the case of bromobenzene dehalogenation was accompanied by arene hydrogenation to form cyclohexane. The substituent on the arene ring has been reported to have an effect on the rate of hydrogenation, such that electron-withdrawing substituents retard the reaction. ${ }^{14}$ The reaction of acetophenone (entry 4) was not a suitable test of the substituent effect because the carbonyl reduction predominantly occurred over the arene hydrogenation. In contrast, the shorter reaction times in entries 13 compared to those in entries 8 and 9 are in agreement with this effect. However, as shown by the comparison of entries 8 and 9 with entries $10-13$, the reaction rate is about the same or even lower when the carbonyl group of an ester or an amide is not directly bonded to the benzene ring. These results may be ascribed to the coordination of the ester and amide carbonyl to the catalyst surface, thereby acting as a catalyst poison. In other words, the results shown in entries 5-9 could be explained by both the electron-withdrawing properties of the cyano-, nitro-, and bromo groups and catalyst poisoning by the lone pair contained in these functional groups. A chiral alcohol, $(R)-1-$ phenylethanol, was subjected to hydrogenation at $30{ }^{\circ} \mathrm{C}$ to give $(R)$-1-cyclohexylethanol in high yield without racemization (entry 14; the details are given in Supporting Information).

Disubstituted arenes, ortho-, meta-, and para-xylene, were hydrogenated to give the corresponding dimethylcyclohexanes in 93,82 , and $89 \%$ yields within $1 \mathrm{~h}$. In all cases, the cis isomers were the major products; the cis/trans ratios were 92/8, 89/11, and $75 / 25$, respectively, which is consistent with the results of reactions catalyzed by other dispersed metal NP systems. ${ }^{7 \mathrm{~b}}$

As described above, the arene hydrogenation would compete with reduction of the oxo group during the reaction of acetophenone (Table 6, entry 4 ). Prolonging the reaction time to $12 \mathrm{~h}$ resulted in complete hydrogenation of both the arene ring and the oxo group to give 1-cyclohexylethanol in $94 \%$ yield (conversion of acetophenone >99\%). In contrast, effective suppression of arene hydrogenation was achieved by the addition of pyridine ( 0.5 equiv. relative to acetophenone) to give 1phenylethanol as shown in Scheme 2. Similar complete and selective hydrogenations were also observed upon using 4phenyl-2-butanone as the substrate. The effect of pyridine on the selective reduction of ketones is similar to that observed for the heterogeneous platinum catalysts. ${ }^{24}$ In sharp contrast, the hydrogenation of benzaldehyde and 3-phenylpropanal afforded benzyl alcohol and 3-phenyl-1-propanol in $89 \%\left(30{ }^{\circ} \mathrm{C}, 12 \mathrm{~h}\right)$ 
and $52 \%\left(50{ }^{\circ} \mathrm{C}, 36 \mathrm{~h}\right)$ yields, respectively. In such cases, only reduction of the aldehyde groups to the corresponding primary alcohols was observed without further hydrogenation of the aromatic ring, even in the absence of pyridine.

Table 6. Hydrogenation of various arenes catalyzed by Ru-1.

(30.33 mol\%)

${ }^{\mathrm{a}}$ All reactions were carried out with the substrate $(1 \mathrm{mmol})$ and Ru-1 ( $\mathrm{Ru}=0.3 \mathrm{~mol} \%, \mathrm{~S} / \mathrm{C}=333)$ in $\mathrm{H}_{2} \mathrm{O}(1 \mathrm{~mL})$. ${ }^{\mathrm{b}}$ For entries 1-7, GC yields with $n$-decane as an internal standard; for entries $8-14$, isolated yields. ${ }^{\mathrm{c}}$ The ratio of 1-cyclohexylethanone to 1 -phenylethanol was $39 / 61$ as determined by ${ }^{1} \mathrm{H}$ NMR. ${ }^{\mathrm{d}}$ Both the starting material and the product were $>99 \%$ ee by chiral GC analysis.
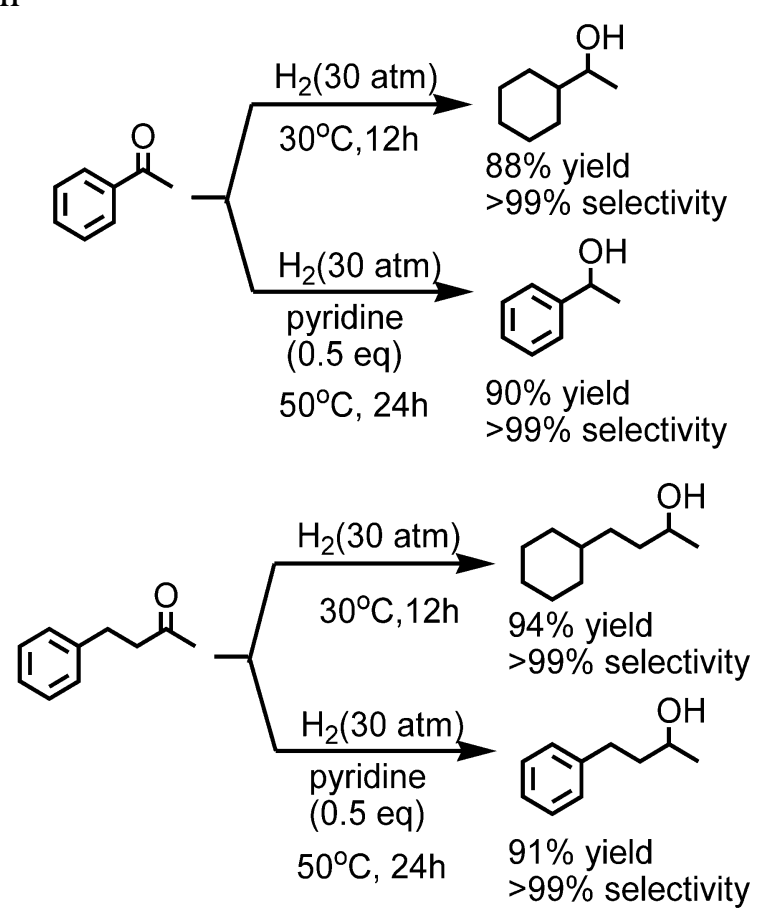

Scheme 2. Selectivity during the hydrogenation of arenes containing carbonyl groups as catalyzed by $\mathrm{Ru}-1$ in the absence or presence of pyridine.

A special feature of $\mathrm{M} @ \mathrm{HPS}-\mathrm{NR}_{3}{ }^{+} \mathrm{Cl}^{-}$is the potential preparation of both water-dispersible and organo-dispersible catalysts, as described above. The organo-dispersible Ru-2 catalyst is applicable to the biphasic hydrogenation of watersoluble substrates. In a typical example, the hydrogenation of 1(2-(2-(2-methoxyethoxy)ethoxy)ethoxy) benzene was performed in benzotrifluoride (BTF) $(\mathrm{S} / \mathrm{C}=100)$ at $30{ }^{\circ} \mathrm{C}$ under $\mathrm{H}_{2}(30 \mathrm{~atm})$ for $24 \mathrm{~h}$ (Scheme 3). The product was readily separated by extraction of the reaction mixture with water, while the catalyst remained in the BTF layer. The desired product was obtained from the combined aqueous layers in over $90 \%$ yield.

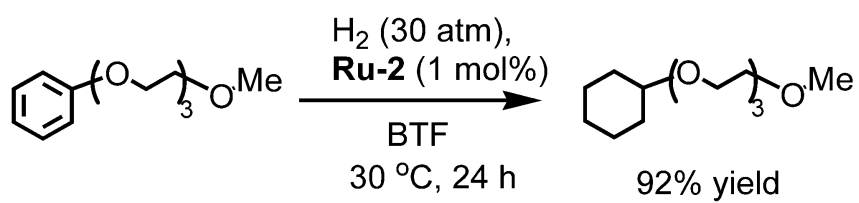

Scheme 3. Hydrogenation of a water-soluble substrate, 1-(2(2-(2-methoxyethoxy)ethoxy)ethoxy) benzene, catalyzed by Ru-2.

\subsection{Catalytic hydrogenation of arene ring with the epoxido- group remaining intact}

It is known that the ring-opening reaction of epoxido groups is significantly promoted by $\mathrm{H}_{2}$ activated by transition metal catalysts. ${ }^{13 a}$ However, it was found during trials with $\mathbf{R u - 1}$ that the benzene rings of several aromatic compounds containing epoxido groups were successfully hydrogenated while the epoxido groups remained intact, as summarized in Table 7 . In entries 1 and 2, the hydrogenations of both phenyl and benzyl glycidyl ethers proceeded smoothly to give the corresponding cyclohexyl compounds. No by-products were observed in either case. The selective hydrogenation of a furan derivative (entry 3 ) gave a tetrahydrofurfuryl glycidyl ether. The product shown in entry 4 represents an important type of compound used as a cross-linking reagent in the production of epoxy resins. ${ }^{25}$ Similar 
to the hydrogenation of para-xylene, the product was also a mixture of cis and trans isomers, at a ratio of 87/13. We have previously reported ruthenium NPs supported by carbon nanofibers (CNFs), which was useful as a reusable catalyst for arene hydrogenation. Although their catalytic efficiency was high (TON > 5000), these Ru@CNFs only catalyzed the reaction at high temperatures $\left(100^{\circ} \mathrm{C}\right)$ at which the ring-opening reaction of epoxido-containing arenes took place. ${ }^{13 b, 13 \mathrm{c}}$ To ensure the successful hydrogenation of aryl and heteroaryl glycidyl ethers while keeping the epoxido group intact it was therefore necessary to use Rh@CNF, which is more expensive than Ru@CNF. ${ }^{13 a}$

Table 7. Hydrogenation of various arenes containing epoxido-groups catalyzed by $\mathbf{R u}-\mathbf{1}^{\mathrm{a}}$

entry substrate

${ }^{\mathrm{a}}$ All reactions were carried out with the substrate $(1 \mathrm{mmol})$ and Ru-1 $(\mathrm{Ru}=0.3 \mathrm{mmol} \%, \mathrm{~S} / \mathrm{C}=333)$ in $\mathrm{H}_{2} \mathrm{O}(1 \mathrm{~mL})$ at $30{ }^{\circ} \mathrm{C}$ under $\mathrm{H}_{2}(30 \mathrm{~atm}) .{ }^{\mathrm{b}}$ Isolated yield. ${ }^{\mathrm{c}}$ Substrate $=0.5 \mathrm{mmol}, \mathrm{S} / \mathrm{C}=$ 56 , in a $1 / 1$ mixture of EtOAc/ $\mathrm{H}_{2} \mathrm{O}(6 \mathrm{~mL})$. ${ }^{\mathrm{d}}$ Isolated yield after column chromatography. The ratio of cis to trans isomers was 87/13 as determined by ${ }^{1} \mathrm{H}$ NMR.
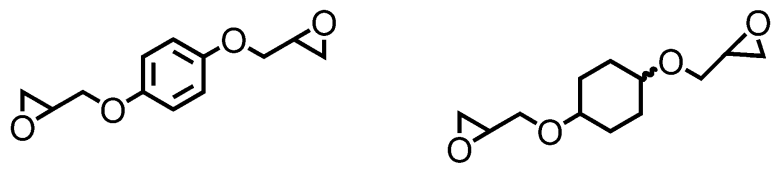

The precursor of entry 4

The product of entry 4

\subsection{Recycling of the catalyst}

The final goal of this study was to demonstrate biphasic hydrogenation and catalyst recycling. Table 8 summarizes four experimental trials regarding catalyst recycling: (A) the hydrogenation of cyclohexene by Rh-1, (B) the hydrogenation of toluene by Ru-1, (C) the hydrogenation of glycidyl phenyl ether by Ru-1, and (D) the hydrogenation of 1-(2-(2-(2methoxyethoxy)ethoxy)ethoxy) benzene by Ru-2. Experiment A was performed at $30{ }^{\circ} \mathrm{C}$ under 1 atm of $\mathrm{H}_{2}$ and an $\mathrm{S} / \mathrm{C}$ of 2000 was found to be suitable for one cycle of the reaction, which was complete in $1 \mathrm{~h}$. The aqueous phase containing Rh-1 was recycled five times without any decline in the catalyst's efficiency and the total TON reached a value of $10,000 .{ }^{26}$ In two additional experiments using $\mathbf{R u}-\mathbf{1}$, the $\mathrm{S} / \mathrm{C}$ was set to 1000 (experiment $\mathrm{B}$ ) and 333 (experiment $\mathrm{C}$ ), and the reactions were carried out at $30{ }^{\circ} \mathrm{C}$ under $30 \mathrm{~atm}$ of $\mathrm{H}_{2}$. Here the catalyst phase could be recycled over five trials while maintaining the catalytic activity. Experiment D was different from the above three trials, such that the Ru-2 was immobilized in the organic phase (BTF). Although a longer reaction time was required to complete the reaction, even with a relatively large catalyst loading $(\mathrm{S} / \mathrm{C}=100)$, the catalyst phase was reusable three times. In all cases, the recovered M@HPS- $\mathrm{NR}_{3}{ }^{+} \mathrm{Cl}^{-}$was subjected to TEM analysis. The particle size of the Rh-1 was observed to be unchanged over the five recycling trials in experiment A. In contrast, a slight increase in the particle size was found during the three experiments using the ruthenium catalysts. For example, the Ru-1 particle size was changed from $1.4 \pm 0.3 \mathrm{~nm}$

Table 8. Catalyst recycling of $\mathrm{M} @ \mathrm{HPS}-\mathrm{NR}_{3}{ }^{+} \mathrm{Cl}^{-}$following biphasic hydrogenation of alkenes and aromatic compounds:

(A) Hydrogenation of cyclohexene to cyclohexane catalyzed by $\mathbf{R h}-1 .^{\text {a }}$

\begin{tabular}{llllll}
\hline Run & 1st & 2nd & 3rd & 4th & 5th \\
\hline Conv $^{\mathrm{b}}(\%)$ & $>99$ & $>99$ & $>99$ & $>99$ & $>99$ \\
\hline
\end{tabular}

${ }^{\mathrm{a}}$ Each experiment was carried out with $\mathrm{S} / \mathrm{C}=2000$ in a biphasic system composed of EtOAc and $\mathrm{H}_{2} \mathrm{O}(1: 1)$ under $\mathrm{H}_{2}$ (1 atm) at 30 ${ }^{\circ} \mathrm{C}$ for $1 \mathrm{~h}$. ${ }^{\mathrm{b}}$ Determined by $\mathrm{GC}$ analysis with $n$-decane as an internal standard.

(B) Hydrogenation of toluene to methylcyclohexane catalyzed by Ru-1.

\begin{tabular}{llllll}
\hline Run & 1st & 2nd & 3rd & 4th & 5th \\
\hline Conv $^{\text {b }}(\%)$ & $>99$ & $>99$ & $>99$ & $>99$ & $>99$ \\
\hline
\end{tabular}

${ }^{a}$ Each experiment was carried out with $\mathrm{S} / \mathrm{C}=1000$ in a biphasic system composed of EtOAc and $\mathrm{H}_{2} \mathrm{O}(1: 1)$ under $\mathrm{H}_{2}$ (30 atm) at $30{ }^{\circ} \mathrm{C}$ for $4 \mathrm{~h}$. ${ }^{\mathrm{b}}$ Determined by $\mathrm{GC}$ analysis with $n$-decane as an internal standard.

(C) Hydrogenation of glycidyl phenyl ether to cyclohexyl glycidyl ether catalyzed by Ru- 1 a $^{\text {a }}$

\begin{tabular}{llllll}
\hline Run & 1st & 2nd & 3rd & 4th & 5th \\
\hline Conv $^{\mathrm{b}}(\%)$ & $>99$ & $>99$ & $>99$ & $>99$ & $>99$ \\
\hline Yield $^{\mathrm{c}}(\%)$ & 90 & 91 & 91 & 90 & 90 \\
\hline
\end{tabular}

${ }^{\mathrm{a}}$ Each experiment was carried out with $\mathrm{S} / \mathrm{C}=333$ in a biphasic system composed of EtOAc and $\mathrm{H}_{2} \mathrm{O}(1: 1)$ under $\mathrm{H}_{2}$ (30 atm) at $30{ }^{\circ} \mathrm{C}$ for $6 \mathrm{~h}$. ${ }^{\mathrm{b}}$ Determined by ${ }^{1} \mathrm{H}$ NMR. ${ }^{\mathrm{c}}$ Isolated yield.

(D) Hydrogenation of 1-(2-(2-(2-methoxyethoxy)ethoxy)ethoxy) benzene to (2-(2-(2-methoxyethoxy)ethoxy)ethoxy) cyclohexane catalyzed by Ru-2. ${ }^{\text {a }}$

\begin{tabular}{llll}
\hline Run & 1st & 2nd & 3rd \\
\hline Conv $^{\mathrm{b}}(\%)$ & $>99$ & $>99$ & $>99$ \\
\hline Yield $^{\mathrm{c}}(\%)$ & 92 & 90 & 92
\end{tabular}

${ }^{\mathrm{a}}$ Each experiment was carried out with $\mathrm{S} / \mathrm{C}=100$ in BTF under $\mathrm{H}_{2}$ (30 atm) at $30{ }^{\circ} \mathrm{C}$ for $24 \mathrm{~h} .{ }^{\mathrm{b}}$ Determined by ${ }^{1} \mathrm{H}$ NMR. ${ }^{\mathrm{c}}$ Isolated yield.

to $1.6 \pm 0.3 \mathrm{~nm}$ in experiment $\mathrm{B}$ (Figure 2). We also assessed the leaching of metallic species into the product in these catalyst recycling experiments. In all cases, the residual amount of metal in the phase containing the product was measured by ICP-MS and it was found that the amount of metal was below the detection limit of the method $(<0.28 \mathrm{ppm})$.

\section{Conclusion}

Rhodium, ruthenium, and iridium NPs with sizes of 1 to $3 \mathrm{~nm}$ were effectively stabilized by the ammonium salts of hyperbranched polystyrene (HPS- $\left.\mathrm{NR}_{3}{ }^{+} \mathrm{Cl}^{-}\right)$. The resulting M@HPS- $\mathrm{NR}_{3}{ }^{+} \mathrm{Cl}^{-}$were sufficiently stable so as to allow their storage either in solution or in the solid state for over a month. The dispersibility of these materials could be tuned by careful selection of the R group; M@HPS- $\mathrm{NBu}_{3}{ }^{+} \mathrm{Cl}^{-}$was dispersible in water but not in toluene and EtOAc, whereas M@HPS$\mathrm{N} n \mathrm{Oct}_{3}{ }^{+} \mathrm{Cl}^{-}$could be dispersed in common organic solvents but not in water. Rh-1 and Rh-2, as well as their palladium and platinum analogues, showed high catalytic activity towards mono-, di-, tri-, and tetrasubstituted alkenes under mild conditions. In contrast, the ruthenium derivatives, $\mathbf{R u - 1}$ and $\mathbf{R u}-$ 2, exhibited good catalytic performance for arene hydrogenation. The hydrogenation of aromatic compounds having various functional groups was achieved by Ru-1 immobilized in an 
aqueous phase. Successful hydrogenation of the aromatic or heteroaromatic ring in several aryl or heteroaryl glycidyl ethers suggested that the present biphasic hydrogenation



\section{$1.4 \pm 0.3 \mathrm{~nm}$}
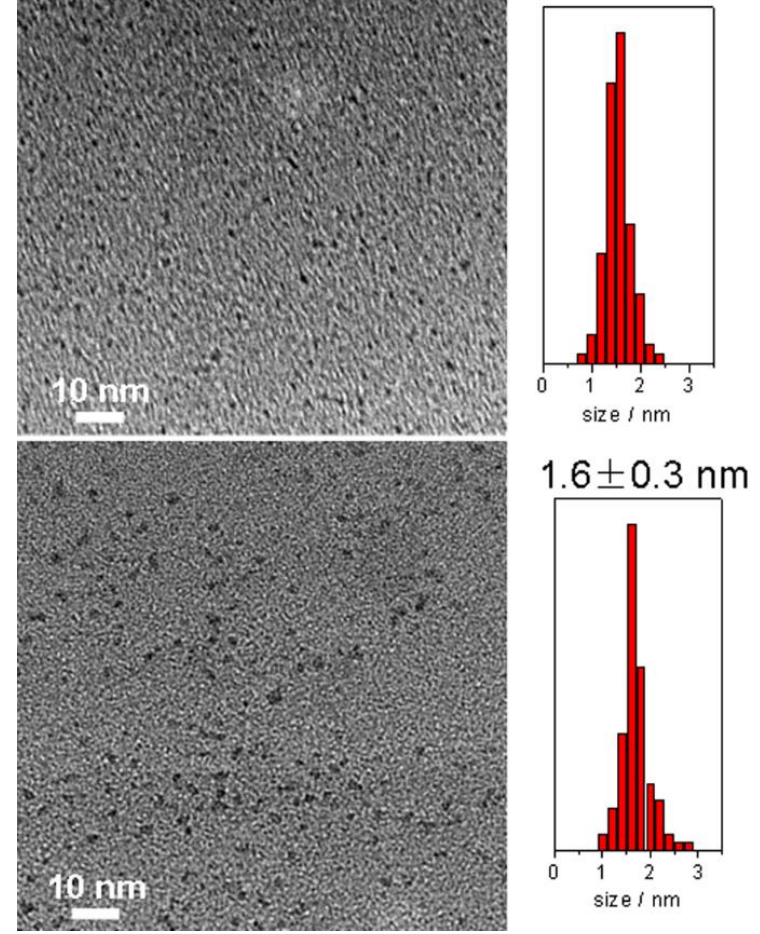

Figure 2. TEM images and particle size distributions of Ru-1: A) before and B) after five repeated cycles of toluene hydrogenation (experiment B). Similar TEM images before and after catalyst recycling trials for the other three reactions (experiments A, C, and D) are provided in the Supporting Information.

is tolerant of functional groups normally sensitive towards acids and bases. Water/organic biphasic hydrogenations were achieved using Ru-1 dispersed in the aqueous phase, and were applicable to the hydrogenation of organo-soluble substrates. In contrast, the immobilization of Ru-2 in BTF led to the successful hydrogenation of a water-soluble substrate. Catalyst recycling trials with phenyl glycidyl ether proceeded smoothly under mild conditions in which the ring-opening reaction of epoxido groups was not observed. The excellent durability of $\mathrm{M} @ \mathrm{HPS}-\mathrm{NR}_{3}{ }^{+} \mathrm{Cl}^{-}$ in catalyst recycling experiments was demonstrated by TEM analysis of the particle size before and after the reactions, with almost no change after several recycling trials. It is important to note that, in all of the catalyst recycling experiments, the catalyst was recyclable without any decline in the catalyst efficiency, and with no leaching of the metal observed in the product. These results clearly demonstrate the utility of $\mathrm{HPS}-\mathrm{NR}_{3}{ }^{+} \mathrm{Cl}^{-}$as a support for second and third row late transition metals, and the promising potential applications of $\mathrm{M} @ \mathrm{HPS}-\mathrm{NR}_{3}{ }^{+} \mathrm{Cl}^{-}$to other catalytic reactions mediated by metal NPs. Finally, we wish to emphasize that homogeneous catalysis has been developed using soluble organometallic complexes as the catalyst. The next generation of homogeneous catalysts should be expanded to include dispersible nanometal particles, which are anticipated to exhibit high catalytic activity as well as possible recycling without metal leaching. The results presented in this paper are considered a step towards the eventual application of such materials.

\section{Experimental section}

\subsection{General methods}

All reagents were used as-received and were obtained from commercial suppliers, with the exceptions of $\mathrm{N}, \mathrm{N}$-dimethyl-3phenylpropionamide $^{27}$ and 1-(2-(2-(2methoxyethoxy)ethoxy)ethoxy) benzene, ${ }^{28}$ both of which were synthesized according to reported methods. The butyl and octyl derivatives of $\mathrm{HPS}-\mathrm{NR}_{3} \mathrm{Cl}$ and their palladium and platinum composites were prepared according to a method reported previously. ${ }^{15}$ The two aldehydes, benzaldehyde and 3phenylpropanal, were distilled under reduced pressure before use, while the other substrates were used as-received. ${ }^{1} \mathrm{H}$ and ${ }^{13} \mathrm{C}$ NMR spectra were acquired on ECA-400 (396 MHz) or ECA$600(600 \mathrm{MHz})$ spectrometers in $\mathrm{CDCl}_{3}$. Transmission electron microscopy (TEM, JEOL JEM-2100F, V=200 kV), high resolution mass spectrometry (HRMS) and inductively coupled plasma mass spectrometry (ICP-MS, Shimadzu ICPM-8500) analyses were performed at the Analytical Center in the Institute for Materials Chemistry and Engineering, Kyushu University. Neither organic by-products nor metal residues were observed during analysis by NMR or ICP-MS in all the cases described below, indicating no further purification was required. To avoid possible contamination by impurities from the solvent or the reagents, isolated yields were determined after passing products through a short chromatographic column, unless otherwise noted. Spectral data for new products are presented below, while data for other products are described in the Supporting Information, and were found to be consistent with those reported in the literature.

\subsection{Preparation of $M @ H P S-N R_{3}{ }^{+} \mathrm{Cl}^{-}(M=R u, R h$, and Ir $)$}

\subsubsection{Preparation of water-dispersible Ru@HPS- $\mathrm{NnBu}_{3}{ }^{+} \mathrm{Cl}^{-}(\boldsymbol{R} \boldsymbol{u}-\mathbf{1}, \boldsymbol{R} \boldsymbol{h}-\mathbf{1}$, and $\mathbf{I r}-\mathbf{1})$}

To an aqueous solution of HPS- $\mathrm{NBu}_{3}{ }^{+} \mathrm{Cl}^{-}(600 \mathrm{mg}$ in $20 \mathrm{~mL}$ of $\left.\mathrm{H}_{2} \mathrm{O}\right)$ was added a solution of $\mathrm{RuCl}_{3} \cdot 3 \mathrm{H}_{2} \mathrm{O}(155 \mathrm{mg}, 0.59$ mmol, in $10 \mathrm{~mL}$ of $\mathrm{H}_{2} \mathrm{O}$ ) with stirring to obtain a dark brown mixture. The resulting solution was cooled to $0{ }^{\circ} \mathrm{C}$ and stirred for 30 min. A freshly prepared aqueous solution of $\mathrm{NaBH}_{4}(223 \mathrm{mg}$, 10 equiv. relative to $\mathrm{Ru}$, in $10 \mathrm{~mL}$ of $\mathrm{H}_{2} \mathrm{O}$ ) was rapidly added to the reaction mixture with vigorous stirring. Immediately the solution turned black, indicating the formation of $\mathrm{Ru}$ nanoparticles. The reaction mixture was stirred for $1 \mathrm{~h}$ at $0{ }^{\circ} \mathrm{C}$ and subsequently subjected to dialysis using a membrane tube with a cutoff molecular weight of $30 \mathrm{kDa}$. After removal of water by freeze-drying, Ru-1 was obtained as a black solid (580 mg).

In a similar fashion, Rh-1 was obtained as a black solid (565 $\mathrm{mg}$ ) from $\mathrm{HPS}-\mathrm{N}_{n} \mathrm{Bu}_{3}{ }^{+} \mathrm{Cl}^{-}\left(600 \mathrm{mg}\right.$ in $20 \mathrm{~mL}$ of $\left.\mathrm{H}_{2} \mathrm{O}\right)$ and $\mathrm{RhCl}_{3} \cdot 3 \mathrm{H}_{2} \mathrm{O}\left(153 \mathrm{mg}, 0.58 \mathrm{mmol}\right.$, in $10 \mathrm{~mL}$ of $\left.\mathrm{H}_{2} \mathrm{O}\right)$ by treatment with $\mathrm{NaBH}_{4}$ (219 mg, 10 equiv. to Rh, in $10 \mathrm{~mL}$ of $\mathrm{H}_{2} \mathrm{O}$ ).

Preparation of Ir-1 (black solid, $552 \mathrm{mg}$ ) was performed using HPS- $\mathrm{NBu}_{3}{ }^{+} \mathrm{Cl}^{-}\left(600 \mathrm{mg}\right.$ in $\left.20 \mathrm{~mL} \mathrm{H} \mathrm{H}_{2} \mathrm{O}\right), \mathrm{IrCl}_{3} \cdot 3 \mathrm{H}_{2} \mathrm{O}(118 \mathrm{mg}$, $0.33 \mathrm{mmol}$, in $10 \mathrm{~mL}$ of $\left.\mathrm{H}_{2} \mathrm{O}\right)$, and $\mathrm{NaBH}_{4}(125 \mathrm{mg}, 10$ equiv. to Ir, in $10 \mathrm{~mL}$ of $\mathrm{H}_{2} \mathrm{O}$ ).

\subsubsection{Preparation of organo-dispersible M@HPS- $\mathrm{NnOct}_{3}{ }^{+} \mathrm{Cl}^{-}(\boldsymbol{R u}-\mathbf{2}, \mathbf{R h}-\mathbf{2}$, and $\mathbf{I r}-2)$}

A $\mathrm{THF} / \mathrm{H}_{2} \mathrm{O}$ mixture $(4 / 1 \mathrm{v} / \mathrm{v})$ was used in the following synthesis procedures. To a solution of HPS-NnOct ${ }_{3}^{+} \mathrm{Cl}^{-}(600 \mathrm{mg}$ in $20 \mathrm{~mL}$ of the aqueous THF) was added a solution of $\mathrm{RuCl}_{3} \cdot 3 \mathrm{H}_{2} \mathrm{O}(155 \mathrm{mg}, 0.59 \mathrm{mmol}$ in $80 \mathrm{~mL}$ of the aqueous THF $)$ with stirring, after which the mixture was cooled to $0{ }^{\circ} \mathrm{C}$ and stirred for $30 \mathrm{~min}$. A solution of $\mathrm{NaBH}_{4}(223 \mathrm{mg}, 10$ equiv. relative to $\mathrm{Ru}$, in $10 \mathrm{~mL} \mathrm{H}_{2} \mathrm{O}$ ) was rapidly added to the 
vigorously stirred reaction mixture. The solution immediately turned black, indicating the formation of $\mathrm{Ru}$ nanoparticles. The reaction mixture was stirred at $0{ }^{\circ} \mathrm{C}$ for $1 \mathrm{~h}$, following which the THF was removed by evaporation and the aqueous layer was extracted with $\mathrm{CHCl}_{3}(20 \mathrm{~mL} \times 5)$. After the combined extracts were dried over anhydrous $\mathrm{Na}_{2} \mathrm{SO}_{4}$, the solvent was removed by evaporation. On vacuum drying, Ru-2 was obtained as a black solid (650 mg).

In a similar manner, Rh-2 was obtained as a black solid (646 $\mathrm{mg}$ ) from HPS-N $n \mathrm{Oct}_{3}{ }^{+} \mathrm{Cl}^{-}(600 \mathrm{mg}$ in $20 \mathrm{~mL}$ of the aqueous THF) and $\mathrm{RhCl}_{3} \cdot 3 \mathrm{H}_{2} \mathrm{O}(153 \mathrm{mg}, 0.58 \mathrm{mmol}$ in $10 \mathrm{~mL}$ of the aqueous THF) by treatment with $\mathrm{NaBH}_{4}(219 \mathrm{mg}, 10$ equiv. to $\mathrm{Rh}$, in $10 \mathrm{~mL}$ of $\mathrm{H}_{2} \mathrm{O}$ ).

Preparation of Ir-2 (black solid, $636 \mathrm{mg}$ ) was performed using HPS- $n \mathrm{Oct}_{3}{ }^{+} \mathrm{Cl}^{-}(600 \mathrm{mg}$ in $20 \mathrm{~mL}$ of the aqueous THF), $\mathrm{IrCl}_{3} \cdot 3 \mathrm{H}_{2} \mathrm{O}(118 \mathrm{mg}, 0.33 \mathrm{mmol}$ in $80 \mathrm{~mL}$ of the aqueous THF $)$, and $\mathrm{NaBH}_{4}\left(125 \mathrm{mg}, 10\right.$ equiv. to $\mathrm{Ir}$, in $10 \mathrm{~mL}$ of $\mathrm{H}_{2} \mathrm{O}$ ).

\subsubsection{Comparison of the catalytic performance of $\mathrm{M} @ \mathrm{HPS}-\mathrm{NR}_{3}{ }^{+} \mathrm{Cl}$ \\ 4.2.3.1. Hydrogenation of alkenes}

The alkenes shown in Tables 2 and $3(2.0 \mathrm{mmol})$ were treated with M@ $\mathrm{HPS}-\mathrm{NR}_{3}{ }^{+} \mathrm{Cl}^{-}(\mathrm{M}=0.004 \mathrm{mmol}, \mathrm{S} / \mathrm{C}=500$, in $2 \mathrm{~mL}$ of $\mathrm{EtOH})$ with stirring at $30{ }^{\circ} \mathrm{C}$ under a hydrogen atmosphere $(1$ atm). Alternatively, the reaction was performed in an autoclave fitted with an inner glass tube under $10 \mathrm{~atm}$ of $\mathrm{H}_{2}$. The mixture was subsequently diluted with diethyl ether and passed through a short column of celite to remove the metal nanoparticles. The conversion of the alkene was determined by GC analysis using $n$ decane as an internal standard, except when employing 2,3dimethyl-2-butene as the substrate, for which the conversion was determined by ${ }^{1} \mathrm{H}$ NMR using mesitylene as an internal standard. In the experiments shown in Table 4, hydrogenation was performed with lower catalyst loadings. Cyclohexene (2 or 4 mmol for $\mathrm{S} / \mathrm{C}=5000$ or 10,000 , respectively) was treated with $\mathrm{M} @ \mathrm{HPS}-\mathrm{N} n \mathrm{Bu}_{3}{ }^{+} \mathrm{Cl}^{-}(\mathrm{M}=0.4 \mu \mathrm{mol})$ in $2 \mathrm{~mL}$ of $\mathrm{EtOH}$ or a mixture of EtOAc $(2 \mathrm{~mL})$ and $\mathrm{H}_{2} \mathrm{O}(2 \mathrm{~mL})$ at $30{ }^{\circ} \mathrm{C}$ under hydrogen $(1 \mathrm{~atm})$. After a work-up similar to that described above, the conversion of the alkene was determined by GC analysis using $n$-decane as an internal standard.

\subsubsection{Hydrogenation of toluene}

In a stainless autoclave fitted with an inner glass tube, toluene (184.2 $\mathrm{mg}, 2.0 \mathrm{mmol})$ was treated with $\mathrm{H}_{2}(30 \mathrm{~atm})$ in the presence of $\mathrm{M} @ \mathrm{HPS}-\mathrm{NR}_{3}{ }^{+} \mathrm{Cl}^{-}(\mathrm{M}=0.004 \mathrm{mmol}, \mathrm{S} / \mathrm{C}=500$, in 2 $\mathrm{mL}$ of EtOH) with stirring at $30{ }^{\circ} \mathrm{C}$ for $1 \mathrm{~h}$. The mixture was diluted with diethyl ether and passed through a short column of celite to remove the metal nanoparticles. The conversion was determined by $\mathrm{GC}$ analysis using $n$-decane as an internal standard. In the trial for which the S/C was set at 2000 , toluene (368.4 $\mathrm{mg}, 4.0 \mathrm{mmol}$ ) was treated with $\mathrm{H}_{2}$ (30 atm) in the presence of Ru-1 or Ru-2 (0.002 mmol in $2 \mathrm{~mL}$ of EtOH) with stirring at $30{ }^{\circ} \mathrm{C}$ for $5 \mathrm{~h}$.

The reaction in $\mathrm{H}_{2} \mathrm{O}$ was carried out as follows. Toluene (92. 1 $\mathrm{mg}, 1.00 \mathrm{mmol})$ was treated with $\mathrm{H}_{2}(30 \mathrm{~atm})$ in the presence of Ru-1 $\left(0.003 \mathrm{mmol}, \mathrm{S} / \mathrm{C}=333\right.$, in $1 \mathrm{~mL}$ of $\left.\mathrm{H}_{2} \mathrm{O}\right)$ with stirring at $30{ }^{\circ} \mathrm{C}$ for $1 \mathrm{~h}$. The mixture was extracted with EtOAc $(3 \mathrm{~mL} \times 5)$, and the conversion was determined by GC analysis using $n$ decane as an internal standard. These reactions were also performed on larger scales [toluene $=24 \mathrm{mmol}(\mathrm{S} / \mathrm{C}=1400)$ and $60 \mathrm{mmol}(\mathrm{S} / \mathrm{C}=4000)]$, as described in the Supporting Information.

\subsubsection{Hydrogenation of substituted benzenes}

In a typical example, a substituted benzene $(1.0 \mathrm{mmol})$, as shown in Table 6 , was treated with $\mathrm{H}_{2}$ (30 atm) with stirring at 30 or $50{ }^{\circ} \mathrm{C}$ in the presence of Ru-1 $(\mathrm{Ru}=0.003 \mathrm{mmol}, \mathrm{S} / \mathrm{C}=333$, in $1 \mathrm{~mL}$ of $\mathrm{H}_{2} \mathrm{O}$ ) in an autoclave with an inner glass tube. The product was extracted with EtOAc $(3 \mathrm{~mL} \times 5)$ and the combined extracts were dried over $\mathrm{Na}_{2} \mathrm{SO}_{4}$ and concentrated under reduced pressure. The crude product was purified using a short silica gel column. The hydrogenation of anisole on a large scale [toluene $=$ $24 \mathrm{mmol}(\mathrm{S} / \mathrm{C}=1400)]$ is described in the Supporting Information.

\subsubsection{Hydrogenation of arenes containing carbonyl groups.}

Hydrogenation reactions of aromatic compounds containing carbonyl groups in the absence of pyridine were carried out in similar manner to those described in Section 4.2.4. A typical procedure in the presence of pyridine was as follows: acetophenone $(120.1 \mathrm{mg}, 1.0 \mathrm{mmol})$ was treated with Ru-1 ( $0.003 \mathrm{mmol}, \mathrm{S} / \mathrm{C}=333$, dissolved in $1 \mathrm{~mL}$ of $\mathrm{H}_{2} \mathrm{O}$ ) in the presence of pyridine $(40.0 \mathrm{mg}, 0.5 \mathrm{mmol})$. The mixture was stirred at $30{ }^{\circ} \mathrm{C}$ under 30 atm of $\mathrm{H}_{2}$ for $12 \mathrm{~h}$, following which the pyridine was neutralized by adding a dilute aqueous $\mathrm{HCl}$ solution. The aqueous layer was extracted with EtOAc $(3 \mathrm{~mL} \times 5)$ and the solution was dried over $\mathrm{Na}_{2} \mathrm{SO}_{4}$. Removal of the solvents under reduced pressure gave the product. In the case of 4-phenyl2-butanone, the reaction was carried out at $50{ }^{\circ} \mathrm{C}$ for $24 \mathrm{~h}$. Hydrogenation of aromatic aldehydes was performed in the absence of pyridine.

\subsubsection{Hydrogenation of arenes containing epoxido- groups}

In a typical procedure, phenyl glycidyl ether $(150.2 \mathrm{mg}, 1.0$ mmol) was treated with Ru-1 $(\mathrm{Ru}=0.003 \mathrm{mmol}, \mathrm{S} / \mathrm{C}=333$, in 1 $\mathrm{mL}$ of $\mathrm{H}_{2} \mathrm{O}$ ) with stirring under $30 \mathrm{~atm}$ of $\mathrm{H}_{2}$ in an autoclave with an inner glass tube for $6 \mathrm{~h}$. The aqueous layer was subsequently extracted with EtOAc $(3 \mathrm{~mL} \times 5)$ and the solution was dried over $\mathrm{Na}_{2} \mathrm{SO}_{4}$. After removal of the solvent, the crude product was passed through a short silica gel column to give the desired product.

1,4-Bis(glycidyloxy)cyclohexane: Colorless oil, a mixture of cis- and trans-. ${ }^{1} \mathrm{H}$ NMR $\delta$ 1.27-1.37 (m, $1 \mathrm{H}$, trans-), 1.50-1.64 (m, 1H, cis-) $1.71-1.84(\mathrm{~m}, 1 \mathrm{H}$, cis- $), 1.96-2.04(\mathrm{~m}, 1 \mathrm{H}$, trans- $)$, 2.58-2.63 (m, 1H, cis- and trans-), 3.09-3.15 (m, 1H, cis-), 3.31$3.37(\mathrm{~m}, 1 \mathrm{H}$, trans- $), 3.39-3.45(\mathrm{~m}, 2 \mathrm{H}$, cis- and trans- $), 3.63-$ $3.73(\mathrm{~m}, 1 \mathrm{H}$, cis- and trans- $) ;{ }^{13} \mathrm{C}$ NMR $\delta 27.3,27.6,29.0,29.2$, $44.65,44.70,51.25,51.30,68.58,68.62,69.2,75.5$. HRMS $\left(\mathrm{FAB}^{+}\right): \mathrm{C}_{12} \mathrm{H}_{21} \mathrm{O}_{4} 229.1443$ (calcd 229.1440).

\subsubsection{The catalyst recycling experiments}

A solution of cyclohexene $(164.2 \mathrm{mg}, 2.0 \mathrm{mmol})$ dissolved in EtOAc $(2 \mathrm{~mL})$ was treated with an aqueous solution of Rh-1 (Rh $=0.001 \mathrm{mmol}, \mathrm{S} / \mathrm{C}=2000$, in $2 \mathrm{~mL}$ of $\mathrm{H}_{2} \mathrm{O}$ ) with stirring at 30 ${ }^{\circ} \mathrm{C}$ under a hydrogen atmosphere $(1 \mathrm{~atm})$. The organic layer was separated using a separatory funnel and the extent of conversion was determined by GC analysis with $n$-decane as an internal standard. The aqueous phase was subsequently applied to another hydrogenation.

Similarly, the hydrogenation of toluene $(368.4 \mathrm{mg}, 4.0 \mathrm{mmol}$, dissolved in $2 \mathrm{~mL}$ of EtOAc) was performed in an autoclave in the presence of Ru-1 $(\mathrm{Ru}=0.004 \mathrm{mmol}, \mathrm{S} / \mathrm{C}=1000$, in $2 \mathrm{~mL}$ of $\mathrm{H}_{2} \mathrm{O}$ ) with stirring at $30{ }^{\circ} \mathrm{C}$ under $\mathrm{H}_{2}(30 \mathrm{~atm})$ for $4 \mathrm{~h}$. The aqueous phase was then applied to another run of the hydrogenation.

Similar catalyst recycling experiments were performed using glycidyl phenyl ether $(150.2 \mathrm{mg}, 1.0 \mathrm{mmol}$ dissolved in $1 \mathrm{~mL}$ of 
EtOAc) as the substrate in the presence of $\mathbf{R u - 1}(\mathrm{Ru}=0.003$ mmol, $\mathrm{S} / \mathrm{C}=333$, in $1 \mathrm{~mL}$ of $\mathrm{H}_{2} \mathrm{O}$ ) for $6 \mathrm{~h}$ with stirring at $30{ }^{\circ} \mathrm{C}$ under $\mathrm{H}_{2}$ (30 atm). The organic layer was separated using a separatory funnel and the aqueous layer was extracted with EtOAc several times. The combined extracts were dried over $\mathrm{Na}_{2} \mathrm{SO}_{4}$ followed by evaporation of the EtOAc under a reduced pressure to obtain the product.

In all the trials described above, five replicate reactions were performed. TEM images before and after the fifth catalytic cycle showed almost no change in the particle size. No hydrolysis of the EtOAc was observed.

\subsubsection{Hydrogenation of 1-(2-(2-(2- methoxyethoxy)ethoxy)ethoxy)benzene and the catalyst recycling}

A solution of 1-(2-(2-(2-methoxyethoxy)ethoxy)ethoxy) benzene (123.2 mg, $0.5 \mathrm{mmol})$ and $\mathbf{R u}-\mathbf{2}(\mathrm{Ru}=0.005 \mathrm{mmol}, \mathrm{S} / \mathrm{C}$ $=100$ ) dissolved in $2 \mathrm{~mL}$ of benzotrifluoride (BTF) was treated with $\mathrm{H}_{2}(30 \mathrm{~atm})$ while stirring in an autoclave with an inner glass tube. After $24 \mathrm{~h}$, the resulting mixture was extracted with $\mathrm{H}_{2} \mathrm{O}$ several times. The BTF layer containing the Ru NPs was dried over $\mathrm{Na}_{2} \mathrm{SO}_{4}$ and subjected to another run of the catalytic cycle. The aqueous solution obtained was repeatedly extracted with $\mathrm{CHCl}_{3}$ and the combined extracts were dried over $\mathrm{Na}_{2} \mathrm{SO}_{4}$. Removal of the solvent gave the product. The catalyst recycling experiments were repeated three times and TEM images before and after the third catalytic cycle indicated only slight changes in the particle size.

(2-(2-(2-Methoxyethoxy)ethoxy)ethoxy)cyclohexane: Colorless oil. ${ }^{1} \mathrm{H}$ NMR $\delta$ 1.14-1.33 (m, 5H), 1.49-1.58 (m, 1H), 1.68-1.80 $(\mathrm{m}, 2 \mathrm{H}), 1.87-1.97(\mathrm{~m}, 2 \mathrm{H}), 3.22-3.30(\mathrm{~m}, 1 \mathrm{H}), 3.38(\mathrm{~s}, 3 \mathrm{H})$, $3.53-3.58(\mathrm{~m}, 2 \mathrm{H}), 3.59-3.71(\mathrm{~m}, 10 \mathrm{H}) .{ }^{13} \mathrm{C}$ NMR $\delta 24.4,26.0$, 32.4, 59.2, 67.3, 70.7, 70.77, 70.79, 71.1, 72.1, 78.2. HRMS $\left(\mathrm{FAB}^{+}\right) \mathrm{C}_{13} \mathrm{H}_{27} \mathrm{O}_{4}: 247.1908$, (calcd 247.1909).

\section{Acknowledgments}

This work was supported by the CREST Program of Japan Science and Technology Agency (JST) Japan and Grant in Aid for Scientific Research from Ministry of Education, Culture, Sports, Science and Technology, Japan (No. 26620089).

\section{References and notes}

1. (a) Sheldon, R. A. Chem. Soc. Rev. 2012, 41, 1437-1451; (b) Catalyst Separation, Recovery and Recycling: Chemistry and Process Design, Cole-Hamilton, D. J.; Tooze, R. P. Eds., Springer: Dordrecht, 2006; (c) Recoverable Catalysts and ReagentsPerspective and Prospective, Gladysz, J. A. Ed. Chem. Rev. 2002, 102, No. 10, 3215-3892; (d) Facilitated Synthesis, Bergbreiter, D. E., Kobayashi, S. Eds. Chem. Rev. 2009, 109, No. 2, 257-838; (e) Uozumi, Y.; Yamada, Y. M. A. Chem. Rec. 2009, 9, 51-65.

2. Representative references for heterogeneous catalysis, see: (a) Augustine, R. L. Heterogeneous Catalysis for the Synthetic Chemist, Marcel Dekker: New York, 1996; (b) Smith, G. V.; Notheisz, F. Heterogeneous Catalysis in Organic Chemistry, Academic: California, 1999; (c) Nishimura, S. Handbook of Heterogeneous Catalytic Hydrogenation for Organic Synthesis, Wiley: New York, 2001.

3. Representative reference for multiphase catalysis, see: (a) Multiphase Homogeneous Catalysis, Cornils, B.; Herrmann, W. A.; Horváth, I. T.; Leitner, W.; Mecking, S.; Olivier-Bourbigou, H.; Vogt, D. Eds., Wiley-VCH: Weinheim, 2005; (b) Regulated Systems For Multiphase Catalysis, Leitner, W.; Hölscher, M. Eds. Springer: Berlin, 2008.

4. Roucoux, A.; Schluz, J.; Patin, H. Chem. Rev. 2002, 102, 37573778 .

5. Typical reviews about transition metal nanoparticles in catalysis: see: (a) Bönnemann, H.; Richards, R. M. Eur. J. Inorg. Chem.
2001, 10, 2455-2480; (b) Astruc, D.; Lu, F.; Aranzaes, J. R. Angew. Chem., Int. Ed. 2005, 44, 7852-7872; (c) Ott, L. S; Finke, R. G. Coord. Chem. Rev. 2007, 251, 1075-1100. (d) Yan, N.; Xiao, C.; Kou, Y. Coord. Chem. Rev. 2010, 254, 1179-1218.

6. (a) Bönnemann, H.; Brijoux, W.; Brinkmann, R.; Fretzen, R.; Joussen, T.; Köppler, R.; Korall, B.; Neiteler, P.; Richter, J. J. Mol. Catal., 1994, 86, 129-177; (b) Bönnemann, H.; Braun, G.; Brijoux, W.; Brinkmann, R.; Schulze Tilling, A.; Seevogel K.; Siepen, K. J. Organomet. Chem., 1996, 520, 143-162.

7. (a) Schulz, J.; Roucoux, A.; Patin, H. Chem. Commun. 1999, 535536; (b) Schulz, J.; Roucoux, A.; Patin, H. Chem.-Eur. J. 2000, 6, 618-624; (c) Mévellec, V.; Roucoux, A.; Ramirez, E.; Philippot, K.; Chaudret, B. Adv. Synth. Catal. 2004, 346, 72-76; (d) Nowicki, A.; Le Boulaire, V.; Roucoux, A. Adv. Synth. Catal. 2007, 349, 2326-2330; (e) Denicourt-Nowicki, A.; Romagné, M.L.; Roucoux, A. Catal. Commun. 2008, 10, 68-70; (f) Hubert, C.; Denicourt-Nowicki, A.; Guegan, J.-P.; Roucoux, A. Dalton Trans. 2009, 7356-7358; Guyonnet Bilé, E.; Denicourt-Nowicki, A.; Sassine, R.; Beaunier, P.; Launay, F.; Roucoux, A. ChemSusChem 2010, 3, 1276-1279; (g) Guyonnet Bile, E.; Sassine, R.; Denicourt-Nowicki, A.; Launay, F.; Roucoux, A. Dalton Trans. 2011, 40, 6524-6531; (h) Pélisson, C.-H.; Hubert, C.; DenicourtNowicki, A.; Roucoux, A. Top. Catal. 2013, 56, 1220-1227, and references cited therein.

8. Toshima, N.; Yonezawa, T. New J. Chem. 1998, 22, 1179-1201, see also the references cited therein.

9. Pellegatta, J.-L.; Blandy, C.; Collière, V.; Choukroun, R.; Chaudret, B.; Cheng, P.; Philippot, K. J. Mol. Catal. A: Chem. 2002, 178, 55-61.

10. (a) Yan, N.; Zhang, J.-g.; Tong, Y.; Yao, S.; Xiao, C.; Li, Z.; Kou, Y. Chem. Commun. 2009, 4423-4425; (b) Yan, N.; Yuan, Y. A.; Dyson, P. J. Chem. Commun. 2011, 47, 2529-2531.

11. (a) Widegren, J. A.; Finke, R. G. J. Mol. Catal. A: Chem. 2003, 191, 187-207; (b) Denicourt-Nowicki, A.; Roucoux, A. Curr. Org. Chem. 2010, 14, 1266-1283; (c) Gual, A.; Godard, C.; Castillon, S.; Claver, C. Dalton Trans. 2010, 39, 11499-11512; (d) Scholten, J. D. Curr. Org. Chem. 2013, 17, 348-363.

12. (a) Fache, F.; Lehuede, S.; Lemaire, M. Tetrahedron Lett. 1995, 36, 885-888. (b) Sajiki, H.; Hattori, K.; Hirota, K. Chem.-Eur. J. 2000, 6, 2200-2204. (c) Hara, Y.; Inagaki, H. Chem. Lett. 2002, 1116-1117.

13. (a) Motoyama, Y.; Takasaki, M.; Yoon, S. H.; Mochida, I.; Nagashima, H. Org. Lett. 2009, 11, 5042-5045; (b) Motoyama, Y.; Takasaki, M.; Higashi, K.; Yoon, S. H.; Mochida, I.; Nagashima, H. Chem. Lett. 2006, 35, 876-877; (c) Takasaki, M.; Motoyama, Y.; Higashi, K.; Yoon, S. H.; Mochida, I.; Nagashima, H. Chem. Asian J. 2007, 2, 1524-1533.

14. (a) Lu, F.; Liu, J.; Xu, J. Adv. Synth. Catal. 2006, 348, 857-861; (b) Lu, F.; Liu, J.; Xu, J. J. Mol. Catal. A: Chem. 2007, 271, 6-13.

15. (a) Kojima, K.; Chikama, K.; Ishikawa, M.; Tanaka, A.; Nishikata, T.; Tsutsumi, H.; Igawa, K.; Nagashima, H. Chem. Commun. 2012 48, 10666-10668. (b) Gao, L.; Nishikata, T.; Kojima, K.; Chikama, K.; Nagashima, H. Chem. Asian J. 2013, 8, 3152-3163. (c) Nishikata, T.; Tsutsumi, H.; Gao, L.; Kojima, K.; Chikama, K.; Nagashima, H. Adv Synth. Catal. 2014, 356, 951-960. (d) Chaiyanurakkul, A.; Gao, L.; Nishikata, T.; Kojima, K.; Nagashima, H. Chem. Lett. 2014, 43, 1233-1235.

16. For reviews of hyperbranched polymers, see: (a) Ifran, M.; Seiler, M. Ind. Eng. Chem. Res. 2010, 49, 1169-1196; (b) Wilms, D.; Stiriba S.-E.; Frey, H. Acc. Chem. Res. 2010, 43, 129-141; (c) Zhou, Y.; Huang, W. Liu, J.; Zhu X.; Yan, D. Adv. Mater. 2010, 22, 4567-4590; (d) Seiler, M. Fluid Phase Equilib. 2006, 241, 155-174; (e) Voit, B. J. Polym. Sci., Part A: Polym. Chem., 2005, 43, 2679-2699; (f) Gao C.; Yan, D. Prog. Polym. Sci. 2004, 29, 183-275; (g) Yates C. R.; Hayes, W. Eur. Polym. J. 2004, 40, 1257-1281; (h) Jikei M.; Kakimoto, M.-A. Prog. Polym. Sci. 2001, 26, 1233-1285;(i) Voit, B. J. Polym. Sci., Part A: Polym. Chem. 2000, 38, 2505-2525; (j) Kim, Y. H. J. Polym. Sci., Part A: Polym. Chem. 1998, 36, 1685-1698.

17. In general, the rate was decreased in the order, $\mathrm{R}-\mathrm{CH}=\mathrm{CH}_{2}>\mathrm{R}-$ $\mathrm{CH}=\mathrm{CH}-\mathrm{R}>\mathrm{RCH}=\mathrm{CR}_{2}>\mathrm{R}_{2} \mathrm{C}=\mathrm{CR}_{2}$; (a) Kraus, M. In Ertl, G.; Knozinger, H.; Wietkamp, J. Ed. Handbook of Heterogeneous Catalysis, Wiley-VCH, Weinheim, 1997; Vol. 3, Chapter 5.3.1. (b) Deem M. W.; Newsam, J. M. J. Am. Chem. Soc. 1992, 114, 7189-7198.

18. (a) Crabtree, R. H. Acc. Chem. Res. 1979, 12, 331-337; (b) Cui, X.; Burgess, K. Chem. Rev. 2005,. 105, 3272-3296.

19. The effects of hydrogen pressure on the reactions catalyzed by Ru-1 and Ru-2 was observed during the hydrogenation of 1- 
octene, which was carried out at $30^{\circ} \mathrm{C}$ for $1 \mathrm{~h}$. The resulting 1octene conversions were trace, 12 , and $>99 \%$ at $\mathrm{H}_{2}$ pressures of 1, 10 , and $20 \mathrm{~atm}$, respectively. The pressure effect during the hydrogenation of toluene is summarized in Table 5. The reaction profiles for the hydrogenations of toluene and anisole in water showed no induction period as shown in the Supporting Information..

20. (a) Quek, X.-Y.; Gua, Y.; Hensen, E. J. M. Catal. Today 2012, 183, 72-78. (b) Mao, H.; Liao, X.; Shi, B. Catal. Commun. 2011, $16,210-214$.

21. We defined the TOF as the number of moles of toluene consumed per mole of ruthenium introduced per hour. Roucoux et al. recently reported the hydrogenation of toluene by ruthenium NPs stabilized with certain organic surfactants under almost the same conditions as shown in Table 6. They defined the TOF as the number of moles of $\mathrm{H}_{2}$ consumed per mole of ruthenium introduced per hour, and reported the TOF for toluene hydrogenation to be $600 \mathrm{~h}^{-1}$. Our TOF of $900 \mathrm{~h}^{-1}$ corresponds to $2700 \mathrm{~h}^{-1}$ according to the definition of Roucoux. See ref. 7d.

22. For a recent review on rhodium nanoparticles for hydrogenation, Guerrero, M.; T. Than Chau, N.; Noel, S.; Denicourt-Nowicki, A.; Hapiot, F.; Roucoux, A.; Monflier, E.; Philippot, K. Curr. Org. Chem. 2013, 17, 364-399.

23. It is known that platinum catalysts also promote arene hydrogenation. ${ }^{2}$ In fact, we observed that Pt-1 shows catalytic activity for the hydrogenation of arenes in water, but only at higher temperatures. ${ }^{15 \mathrm{~d}}$
24. Fujiwara, Y.; Iwasaki, Y.; Maegawa, T.; Monguchi, Y.; Sajiki, H. ChemCatChem 2011, 3, 1624-1628.

25. Remeikyte, A.; Ostrauskaite, J.; Grazuleviciene, V. J. Appl. Polym. Sci. 2013, 129, 1290-1298.

26. As noted in Table 4, the highest TOF obtained for Rh-1 during cyclohexane hydrogenation was 8700 after $1 \mathrm{~h}$. Similar TOF values have been reported using rhodium NPs stabilized by PVP or other water soluble polymers, although the reaction conditions were somewhat more harsh. ${ }^{20}$ We performed the catalyst recycling five times, using $\mathrm{S} / \mathrm{C}=2000$ for each cycle, obtaining a total TON value of 10,000 during the recycling trials.

27. Hobbs, C. F.; Weingarten, H. J. Org. Chem. 1968, 33, 2385-2388

28. Kimura, M.; Kajita, K.; Onoda, N.; Morosawa, S. J. Org. Chem. 1990, 55, 4887-4892. 


\section{Graphical Abstract}

To create your abstract, type over the instructions in the template box below.

Fonts or abstract dimensions should not be changed or altered.



